\title{
She Wears The Pants: Fashion, Gender, And Power Dynamics In Pardo Bazán's "Feminista"
}

\author{
Jennifer Smith \\ (SOUTHERN ILLINOIS UNIVERSITY) \\ smithjen@siu.edu
}

(recibido xullo/2019, aceptado novembro/2019)

RESUMEN: La conexión que el relato "Feminista" (1909) hace entre los papeles de género, la dinámica del poder y la moda se hace eco de los ensayos y artículos periódisticos que Pardo Bazán escribió para abogar para reformas en la moda femenina que harían que la mujer estuviera más cómoda, sana y libre en sus movimientos, y en que afirma que la moda actual desempeña un papel crucial en la "esclavitud" de la mujer. Entre los cambios de moda que respalda, menciona el divided skirt, esencialmente un precursor de pantalones para mujer. Por lo tanto, sotengo que el travestismo en que participa la pareja del cuento hace un comentario intenciondado sobre el papel que tiene la moda en el mantenimiento o subversión de los roles tradicionales del dominio masculino y la sumisión femenina. También conecta con la famosa acuarela de Pardo Bazán vistiéndose unos pantalones masculinos.

PALABRAS CLAVE: moda, travestismo, papeles de género, desigualdad de género, gender performance, violencia doméstica.

ABSTRACT: The connection the short story "Feminista" (1909) makes between gender roles, power dynamics, and fashion echoes essays and journalistic pieces Pardo Bazán wrote to advocate for fashion reforms that allow for women's comfort, mobility, and health, and in which she asserts that current fashion trends play a pivotal role in women's "slavery." Among the fashion changes she endorses is the divided skirt, essentially a precursor to pants for women. Thus, I argue that the transvestism the couple in the story engages in makes a pointed commentary on fashion's role in either the maintenance or subversion of the traditional roles of male dominance and female submission. It also connects to the famous water color image of Pardo Bazán slipping on a pair of male trousers.

KEY WORDS: fashion, crossdressing, gender roles, gender inequality, gender performance, domestic abuse.

Feminist positions on women's relation to clothing and fashion have always been divided, to say the least. Essentially there have been two conflicting perspectives, one which views fashion as a form of patriarchal subjugation and another which views it as means to 
empowerment (Tyner and Ogle, 2009: 112). Feminists' initial antagonistic relationship to fashion and beauty had its roots in the nineteenth-century dress reform movement in the United States against restrictive and unhealthy fashion trends such as corsets and overly long and cumbersome skirts. These women argued that fashion physically inhibited women, making them both ill and incapable of serious work outside the home, arguments Emilia Pardo Bazán herself reiterated in essays and journalistic pieces. In "La reforma integral del traje en los EE.UU. (de interés para las damas)" (1890) ${ }^{1}$ Pardo Bazán advocates for fashion reforms that would allow for women's improved comfort, mobility, and health. She states that in the United States, fashion has changed to accommodate women's increased engagement in serious and lucrative activities that require practical attire, the most notable change being the appearance of the divided skirt (López Quintáns, 2013). Pardo Bazán also praises the divided skirt, a clear precursor to pants for women, that same year in Por Francia y por Alemania (1890). Stating that this fashion change could contribute to a social revolution, she writes (52-53):

Ya comprenderéis, joh severos lectores y lectoras asustadizas! Que hablo del divided skirt, ó sea del traje con pantalones.

Sólo se escandalizarán los pusilánimes. Yo no. Me parecerá siempre más escandaloso que la mujer se degrade y caiga en la abyección por no poder ganarse honradamente la vida, que ver expuesto en un escaparate un traje airoso y práctico, cuya creación, obra de eminente sastre inglés, se debe a la necesidad en que se ven muchas norteamericanas de andar aprisa y no enredarse en las enaguas cuando suben a tranvías, coches y barcos de vapor.

[...] Yo creo que el sastre del traje partido es un genio que se adelanta á su siglo y á su era.

The Galician author, likely hoping to win over even some of her more conservative readers, argues in "La reforma integral del traje en los EE.UU." that these changes are necessary for all women since medicine and hygiene are calling for women to be more active -along with clothing that accommodates such activity- in order to avoid the illnesses (physical and psychological) of an overly sedentary lifestyle, disorders that, she asserts, affect the wellbeing of a woman's children (López Quintáns, 2013). Other reforms she embraces in this same piece are shorter skirts that are easier to walk in and that don't trap all the dust and debris from the streets, and undergarments such as the chemilette, than can be worn under the divided skirt, and the model bodice because, unlike the corset, it was less restrictive and didn't damage the internal organs (López Quintáns, 2013). Lamenting that practical clothing for women in Spain can only be seen in sports and hunting, she ends her piece comically by saying that her clothing activism will be limited to advocating for

\footnotetext{
${ }_{1}$ This essay originally appeared in El Guadalete. Periódico Político y Literario, vol. 36, no. 10.627, Novemeber 10, 1890 and is reproduced in its entirety in Javier López Quintáns's article "Tres textos dispersos de Emilia Pardo Bazán: 'La reforma integral del traje en los Estados Unidos (de interés para las damas),' 'Más indumentaria, de interés para los dos sexos' y 'La mujer periodista."”
} 
the divided skirt in writing, hoping that a young, attractive Spanish woman will make it fashionable by actually wearing it in public (López Quitáns, 2013).

Indeed, as the title of Pardo Bazán's article "La reforma integral del traje en los EE.UU. (de interés para las damas)" already indicates, her arguments in favor of clothing reform for women are simply a reiteration of those used by the nineteenth-century dress reform movement in the United States, arguments that Robert E. Riegel in "Women's Clothes and Women's Rights" (1963: 390) summarizes as follows:

The feminist objections to current styles were based in part on the socially acceptable grounds of feminine health. Long skirts swept the ground collecting the unspeakable filth that lay ankle deep on contemporary streets; they were voluminous and difficult to handle [...]. Tightly corseted waists rearranged the vital organs, encouraging the frequent and well-advertised feminine ill health. [...] Not only feminists, but doctors and educators, deplored fashionable dress, moaning that women were courting sickness and death, and were becoming unable to perform normal housework and to bear healthy children.

While Pardo Bazán initially stopped short of making the more bold and controversial arguments of American feminists who also claimed that "Feminine apparel was designed consciously to hamper women's movement and thus prevent them from earning their livings except through marriage" (Riegel, 1963: 391), eighteen years later, in 1908, in her column "La vida contemporánea" (730) she makes just such an argument and goes on to argue that certain fashion trends uphold women's slavery:

Ciertas modas y ciertos estilos van contra lo poco que ha progresado la mujer. Observemos cómo la moda encierra un sentido simbólico. En Turquía el velo, en China la deformación del pie, son el símbolo de la sujeción y del atraso de las hembras. Si en Europa prevalecen hechuras que imposibilitan á la mujer para andar, entrar, salir, moverse, hacer vida activa, en suma, es lo mismo que desandar los cortos pasos andados y volver á los tiempos de la pierna quebrada, las rejas y los cerrojos. La esclavitud femenina está apuntalada también por la moda.

She even advocates for the formation of a "Sindicato de senõras elegantes" which, she writes, would do as much, if not more, to improve women's situation than the suffragist movement (Pardo Bazán, 1908: 730):

Debiera establecerse un Sindicato de señoras elegantes -en los países donde se confeccionan los modelos y se guisan las novedades- para rechazar enérgicamente toda innovación contraria á la comodidad. Que discurran y varíen sin causar molestias, sin atentar á lo más precioso, la salud y la facilidad del existir. Esas señoras sindicadas imponiéndose en los modistos, haciendo el vacío á las invenciones funestas, serían más útiles á su sexo que las sufragistas - ó por lo menos, tanto. 
The following year, 1909², Pardo Bazán publishes her short story "Feminista," which gives fictional representation to her statement on the way female fashion represents female subjugation and debasement. Indeed, the Galician author herself acknowledged in Cuarenta días en la exposción (1901) that "La moda no es algo arbitrario. Por eso merece considerarse como importante manifestación social y artística” (Pardo Bazán, 1901: 104; qtd in López Quintáns 2013).

By the early twentieth century, and despite the gradual disappearance of the fashion reform movement, women's clothing styles continued to change dramatically in order to accommodate women's increased participation in society. This leads Robert Riegel to assert that "Improved clothes had in fact played no part in feminine emancipation, but feminine emancipation had brought greater dress reform than the most visionary of the early feminists had advocated" (1963: 401). However, whether fashion brought about changes in women's status, or whether women's status brought about changes in fashion is most certainly up for debate. The early twentieth-century Spanish writer Carmen de Burgos, for example, argued that fashion itself actually erased class and gender differences. In regard to class she states that: "La moda tiende a igualarlo todo. Esa diferencia que existía en el aspecto exterior de la gran dama, la burguesa y la mujer de conducta dudosa, ha desaparecido. Todas visten lo mismo. No se diferencia de una simple señora, una Princesa o una Reina. Está todo permitido" (Burgos, 1927: 262; qtd in Johnson 2018: 61) ${ }^{3}$. And taking on the question of fashion and gender she notes the way the clothes between the sexes are becoming more and more similar and concludes her discussion on fashion by noting that: "La única conquista que no ha realizado la mujer en la moda ha sido la del pantalón. La tentativa de la falda pantalón fué rechazada escandalosamente por los hombres" (Burgos, 1927: 262). However, as Roberta Johnson notes, pants for women was "a practice that was, in fact, just around the corner" (2018: 62).

After the disappearance of the dress reform movement in the early twentieth century, it was not until the 1980s that questions of fashion and beauty were taken on again seriously by feminist theorists. Feminist authors such as Naomi Wolf (The Beauty Myth: How Images of Beauty Are Used against Women, 1990) and Susan Faludi (Backlash: The Undeclared War against Women, 1991) argued that fashion and beauty ideals worked only to instill insecurity in women about their bodies, leading them to spend inordinate amounts of time and money on their appearance rather than on more meaningful activities (Tyner and Ogle 2009: 102). In contrast, other writers, such as Susan Estrich (Sex and Power, 2001), Nancy Etcoff (Survival of the Prettiest: The Science of Beauty, 1999) and Harriet Rubin (The Princessa: Machiavelli for Women, 1998) argued that sexual attractiveness can be a form of empowerment that has real social and economic payoffs evidenced by women's successful

\footnotetext{
${ }^{2}$ According to Herrero Figueroa, the story was published in 1909 in Sud-exprés (Otros cuentos) (2010-2011: 57 , nota 1).

3 Pardo Bazán also discusses the way in which fashion has erased class distinctions in her 1908 column "La vida contemporánea" (730). For more on the question of Pardo Bazán's views on fashion and social class see my article "Cultural Capital and Social Class in Emilia Pardo Bazán's 'La mujer española' and Insolación.” For an analysis of the author's treatment of feminine fashion in Insolación, see Dorota Henegan's Striking Their Modern Pose: Fashion, Gender, and Modernity in Galdós, Pardo Bazán, and Picón
} 
use of their sexuality to improve their social standing (Tyner and Ogle, 2009: 109). The Spanish writer Lucía Etxebarria, for example, exemplifies such an attitude when she writes that "Ser feminista no [...] implica renunciar al sujetador, el lápiz de labios, los tacones de aguja y los pendientes. Se trata de reclamar al poder de las mujeres y el derecho de cada una de nosotras a utilizar ese poder según nuestros propios términos" (Etxebarria, 2000: 15; qtd in Johnson 2018: 65).

Perhaps most useful to examining the questions of fashion and gender in Pardo Bazán's "Feminista," however, are contemporary feminist theories on the body informed by the work of Michel Foucault. Foucault's decentralized concept of power has been used to undermine ideas of beauty and fashion as a male conspiracy imposed on women and to substitute them with a focus on the ways in which the body, specifically the dressed female body, has been made to perform gender by a variety of social and cultural forces. In "Foucault, Femininity, and the Modernization of Patriarchal Power" (1988), Sandra Bartky states that: "The disciplinary power that inscribes femininity in the female body is everywhere and it is nowhere; the disciplinarian is everyone and yet no one in particular (74). She adds that:

Insofar as the disciplinary practices of femininity produce a 'subjected and practiced,' an inferiorized, body, they must be understood as aspects of a far larger discipline, an oppressive and inegalitarian system of sexual subordination. This system aims at turning women into the docile and compliant companions of men just as surely as the army aims to turn its raw recruits into soldiers. (Bartky, 1988: 75)

Thus, for Bartky, it is specifically women's performance of femininity through the practice of culturally constructed feminine behaviors and fashion trends that makes them complicit, although sometimes unwittingly, in their own subordination. In this gender regime, clothes are one of the principle ways in which the body is made to signify sex and gender for, as Joanne Entwistle notes "Conventions of dress transform flesh into something recognizable and meaningful to a culture and are also the means by which bodies are made 'decent,' appropriate and acceptable within specific contexts" (2000: 323-324). While there are explicit forms of dress requirements, such as when uniforms are required in the workplace, schools, or prisons, there are also implicit requirements such as in white collar jobs in which professional attire is simply understood to be expected (Entwistle, 2000: 330). When it comes to questions of gender, similar explicit and implicit rules apply (Entwistle, 2000: 329). For example, in the late nineteenth century, as we have seen, the divided skirt for women was implicitly discouraged whereas cross dressing was strictly forbidden ${ }^{4}$. But, if

\footnotetext{
${ }^{4}$ We know that female cross dressers were occasionally arrested in the US, although, according to Riegel, they were never formally charged since there were no laws prohibiting male impersonation (1963: 397). And while no woman was ever arrested for wearing the divided skirt, cultural pressures prevented women from wearing it. Pardo Bazán, for example, laments that even in París there are no women bold enough to wear the divided skirt in public: "Dícese que un sastre ó modista ofreció premios en metálico á las primeras que se echasen á la calle con el pantaloncillo á la zuava. Increíble parece que de tanta mujer como anda por París deseando exhibirse, no haya tres que se concierten para hacerse en un día más famosas y nombradas que Edison y Eiffel. ¡Es que salir así pide más valor moral que entrar en el cuarto de un varioloso ó ponerse ante la boca de un cañón cargado para recibir la bala" (Por Francia y por Alemania 1899, 53). And Carmen de Burgos in La mujer moderna y sus derechos (1927) states that: "La tentativa de la falda pantalón fué rechazada escandalosamente por los hombres. Sólo con el uso del pijama ha logrado la mujer satisfacer el deseo de usar esta prenda” $(1927 ; 262)$.
} 
the body is, by nature, one sex or another, why is clothing so regimented by culture, and why is crossdressing so threatening for many?

Judith Butler's response to this question is to argue that the binary gender identities, as we know them, are not natural but rather socially constructed and fixed through reiterative practices or performances, which obviously include attire (Tyner and Ogle, 2009: 105). According to Butler, "The view that gender is performative [seeks] to show that what we take to be an internal essence of gender is manufactured through a sustained set of acts, posited through the gendered stylization of the body. In this way, it show[s] that what we take to be an 'internal' feature of ourselves is one that we anticipate and produce through certain bodily acts" (2007: xv-xvi). Butler argues that crossdressing, or drag, both helps see more clearly the performative nature of gender and confuses our ability to distinguish between a person's "real" gender and "artifice" (2007: xxiii-xxv). A drag queen who successfully passes as a woman, for example, leaves one unable to determine whether the body is that of a man or a woman and causes a gender crisis in that "it become unclear how to distinguish the real from the unreal" (2007: xxiv). Does a drag queen's successful performance of femininity reveal that he is truly, in essence, feminine, or does it emphasize his essential manliness that cannot be disguised by feminine attire? The very fact that the answer is not clear reveals that the gender one performs and the sex of one's body have no inherent correlation; people are socialized to adopt feminine and masculine behaviors as culture dictates, and those cultural norms do not necessarily signal an essential gender.

While the views of feminists such as Bartky and Butler are by no means the last word on the complex and controversial topics of gender, feminism, and fashion, they are fruitful for examining the issues raised in Emilia Pardo Bazán's 1909 short story "Feminista," about a young woman who marries an older man who was an incorrigible womanizer in his youth and remains an outspoken defender of the traditional gender order. To ensure that Clotilde knows her place in the marriage from day one, the morning after their wedding night Nicolás orders her to put on his pants, telling her that from this day forward she will never wear them again. Clotilde fulfills her role as submissive wife until Nicolás falls terminally ill and becomes physically dependent on her. During this time the initial power dynamic of the marriage is inverted, and is given symbolic representation when, every morning, Clotilde orders Nicolás to put on her petticoat so that he understands that from now on he will wear the petticoat in this marriage.

Estrella Cibreiro has argued that Clotilde's actions balance the scales of gender relations and are not intended only to punish and take revenge on her husband, but more importantly to vindicate Clotilde (2017: 78). Maryellen Bieder argues that the narrative structure of the story "maneuvers the reader into accepting a radical violation of gender boundaries" (1993: 150). Araceli Herrero Figueroa, on the other hand, has read this story as an example of reciprocal domestic abuse and revenge where real gender inequality is not achieved (20102011: 57-58; 67). No critic, however, has attempted to unpack the premise that women's clothing in and of itself is degrading, or to question whether the violence in the story is truly equal. Why is it a given that forcing someone (either male or female) to dress in typically female clothing abuse? And why do we automatically assume men's clothes, especially 
pants, represent respectability and empowerment? Finally, how is the sartorial violence equal when Clotilde was subjected to it her an entire life, without cause, both by society and her spouse, but her husband, despite his abusive behavior, was only forced to wear women's clothes in the privacy of the home, and during the final years of his life?

It is my assertion that the transvestism the couple engages is not merely symbolic but actually makes a pointed commentary on fashion's role in either the maintenance or subversion of the traditional roles of male dominance and female submission. It draws attention to the way in which the body is made to perform gender largely through fashion. The symbolism of pants (pantalones) and petticoats (enaguas) is immediately clear to the reader, as Herrero Figueroa notes, "aquí los pantalones se configuran como metáfora de la potestas y auctoritas, frente a las enaguas (ropa interior, que no faldas), símbolo de la sumisíon y luego del travestismo humillante" (2010-2011: 67). Carmen de Burgos's words here are also apropos: "El hombre llegó a hacer del pantalón el signo de su virilidad. Es corriente la frase, 'En mi casa no hay más pantalones que los míos' cuando quiere asentar su supremacía" (1927: 250). What is less clear is what message are we to take from the forced cross dressing that takes place in the story.

We are privy to the details of the relationship between Nicolás Abréu and Clotilde Pedregales though two intra- and homodiegetic narrators. The first narrator, whose ungendered voice ${ }^{5}$ opens the story, tells us of how s/he met the couple at the balneario. S/ he describes Nicolás as annoying, disdainful, argumentative, bitterly pessimistic, arrogant, contradictory, judgmental, verbally aggressive, and ultra-reactionary on questions of gender. According to Nicolás (Pardo Bazán, 1996: 112):

Los tiempos eran fatídicos y la relajación de las costumbres horripilaba. En los hogares reinaba la anarquía, porque, perdido el principio de autoridad, la mujer ya no sabe ser esposa, ni el hombre ejerce su prerrogativas de marido y padre. Las ideas modernas disolvían, y la aristocracia, por su parte, contribuía al escándalo. Hasta que se zurciesen muchos calcetines no cabía salvación. La blandenguería de los varones explicaba el descoco y garrulería de las hembras, las cuales tenían puesto en olvido que ellas nacieron para cumplir deberes, amamantar a sus hijos y espumar el puchero.

The second narrator, a medical doctor who also met Nicolás Abréu at the health resort spa, shares the first narrator's negative opinions. He refers to Nicolás condescendingly as "el

\footnotetext{
${ }^{5}$ Cibreiro argues that the initial narrator is female because the reader is inclined to associate her with the author herself (79), I imagine because of the narrator's use of the first person. Bieder argues that uncertainty of the narrator's gender is a strategy that "transmits the story's challenge to traditional gender relations" (1993: 149). If I had to assign a gender to the initial narrator I would also conjecture that she is female and an alter-ego of the author, but not simply because of the use of the first person since we know of Pardo Bazán's tendency to play with the gender of her first-person narrators, but because Nicolás goes to great extent to give his harangues against feminist reforms when the narrator is present, and the narrator takes great care to simply be nonreactive to his diatribes, suggesting that the narrator is a feminist like Pardo Bazán herself, "Habiendo yo notado que al hallarme presente arreciaba en sus predicaciones el buen señor, adopté el sistema de darle la razón para que no se exaltase demasiado" (1909: 112). That said, Susan Walter has read this same passage as evidence that the narrator is likely male (153-54).
} 
de los pantalones" and asserts that, because of his bragging, he must have been "el más solemne majadero" (Pardo Bazán, 1996: 114).

Most incriminating, however, are Nicolás's moral hypocrisy and ill treatment of his wife. The medical doctor informs us that he only became a moral conservative after having had to abandon his wanton lifestyle due to health issues, "Es el caso que Abréu, como todos los que a los cuarenta años se vuelven severos moralistas, tuvo una juventud divertida y agitada. Alifafes y dolamas le llamaron al orden, y entonces acordó casarse, como él que acuerda mudarse a un piso más sano" (Pardo Bazán, 1996: 114). Shortly afterwards, the doctor insinuates that Nicolás suffers from a venereal disease contracted before his marriage: "Pero Abréu, a pesar de la higiene conyugal, tenía el plomo en el ala. Los restos y reliquias de su mal vivir pasados remanecieron en achaques crónicas, y la primera vez que se consultó conmigo en Aguascaras, vi que no tenía remedio" (Pardo Bazán, 1996: 116). The "plomo en el ala" is a reference to the disease Nicolás contracted from his "mal vivir pasado," most likely either syphilis or gonorrhea ${ }^{6}$. Both diseases, before the invention of antibiotics in the twentieth century, could lead to serious chronic complications and death ("What are the Types?", "Gonorrhea"). We know that Nicolás limps and suffer from arthritis (Pardo Bazán, 1996: 116). Arthritis and joint pain are one of the main symptoms of late stage untreated gonorrhea ("Gonorrhea"). Similarly, Nicolás's limping could be due to the numbness and uncontrollable muscle movements associated with tertiary syphilis ("What are the Types?"). And just as Nicolás's illness did not reappear until after his marriage, both syphilis and gonorrhea fall dormant for some time before reappearing in their last stages ("What are the Types?", "Gonorrhea"). Finally, there is a reference to the "curas prolijas y dolorosas" (Pardo Bazán, 1996: 117). Nineteenth century treatments for syphilis and gonorrhea included mercury, which had a purgative effect and, as we now know, is toxic to the human body (Frith, 2012: 53). While marriage or "la higiene conyugal" was indeed prescribed as a prophylactic against these diseases, it clearly could not cure them once contracted.

Despite showing no repentance about his own former lifestyle, Nicolás constantly rails against society's lax values. The first narrator makes a reference to the contradictions in his thinking only to then extend it to Spaniards in general (Pardo Bazán, 1996: 111):

su modo de pensar era entre inquisitorial y jacobino, mezcla más frecuente de lo que se pudiera suponer, aquí donde los extremos no sólo se han tocado, sino que han solido fusionarse en extraña amalgama. Han sido generalmente prendas raras entre nosotros la flexibilidad y delicadeza de espíritu, engendradoras de la amable tolerancia.

Nicolás's masculine arrogance and sense of entitlement are made most evident, however, in the scene in which he forces Clotilde to wear his pants as he humiliates and threatens her (Pardo Bazán, 1996: 114):

\footnotetext{
6 Because of the similarities between the two diseases, it was not until 1838 that it was firmly established the syphilis and gonorrhea were actually two different diseases (Frith, 2012: 52).
} 
La mañana siguiente a la boda, al despertar la novia, en el asombro del cambio de su destino, oyó que el novio, entre imperioso y sonriente, mandaba:

-Clotilde mía..., levántate.

Hizolo así la muchacha, sin darse cuenta del por qué: y al punto el esposo, con mayor imperio, ordenó:

-¡Ahora..., ponte mis pantalones!

Atónita, sin creer lo que oía, la niña optó por sonreír a su vez, imaginando que se trataba de una broma de luna de miel..., broma algo chocante, algo inconveniente..; pero ¿quién sabe? ¿Sería moda entre novios?...

-¿Has oído i --repitió él--¡Ponte mis pantalones! ¡Ahora mismo, hija mía!

Confusa, avergonzada, y ya con más ganas de llorar que de reír, Clotilde obedeció lo mejor que pudo. ¡Obedecer es ley!

-Siéntate ahora ahí-dispuso nuevamente el marido, solemne y grave de pronto, señalando a una butaca. Y así que la empantolonada niña se dejó caer en ella, el esposo pronunció:

-He querido que te pongas los pantalones en este momento señalado para que sepas, querida Clotilde, que en toda tu vida volverás a ponértelos. Que los he de llevar yo, Dios mediante, a cada hora y cada día, todo el tiempo que dure nuestra unión, y ojalá sea muchos años, en santa paz, amén. Ya lo sabes. Puedes quitártelos.

Having Clotilde put on his pants is Nicolás's way of forcing her to acknowledge her unequal status in society and in their marriage (men are allowed to wear pants and enjoy other rights that women are denied), and threatening her implicitly with physical violence if she were to do anything thing that would usurp his authority in the marriage (if she were to try to wear the pants, metaphorically speaking). His actions also destroy the prospects of any intimacy or true affections in their relationship. To add insult to injury, Nicolás tells everyone about his humiliation of his wife the day after their wedding, thereby also subjecting her to public shame in order to make himself look better at her expense, or at least so he thinks: "Abréu, que debía de ser el más solemne majadero, anduvo jactándose de ello como de una agudeza y un rasgo de carácteres, que convendría que imitasen todos los varones para cimentar solidamente los fueros del cabeza de familia" (Pardo Bazán, 1996: 114).

One of the most notable details about this first crossdressing scene is that Clotilde is being ordered to wear the clothes that she will never be allowed to wear again. Put otherwise, the violence is in the fact that she is being granted a momentary symbolic privilege only to underscore that she will never exercise this privilege again in her life. It is not the pants per se, but the message and harsh words that ensue, along with the subsequent imposition of her usual feminine attire, that constitute abuse. The pants themselves, are not the source of shame. This makes sense considering that historically female cross-dressing has been less harshly judged than male crossdressing because a man who puts on feminine clothing is assuming a subordinate status while a woman who puts on masculine clothing is assuming a more dominant position (Selcuk, McCreary, Mahalik, 2004: 119). Even today, in most Western societies, women can wear many traditionally male clothes (i.e., pants, suit jacket) without raising an eyebrow, whereas traditionally feminine clothes (i.e., skirts and 
dresses) on men are still shocking and even proscribed. Thus, what this cross-dressing scene underscores is that it is the normal feminine clothes that Clotilde is forced to wear, not the pants, that are subjugating, not only because they are physically uncomfortable and inhibit movement (which was most certainly the case), but because they symbolically represent her powerless position in society. The female body, through clothing, is forced to signify its subordinate status not entirely unlike the way symbolic clothing has been imposed on other marginalized groups, such as Jews and gypsies, to publicly mark their social inferiority. However, an unintended consequence of Nicolás's actions is that they emphasize the ways in which gender is constructed in part by fashion because the suggestion is that if Clotilde were allowed to wear pants, the gender dynamics in their marriage might indeed be different. In other words, he explicitly orders her to perform her proper gender role through appropriate attire because her crossdressing would, to use Butler's words, reveal that her gender "is not as fixed as we generally assume it to be" and would "expose the tenuousness of gender 'reality'" and "counter the violence performed by gender norms" (2007: xxv). The fact that Nicolás feels the need to threaten his wife shows how fragile this artificial gender binary is as he believes it can only be held in place by explicit coercion and the implicit threat of violence. It also substantiates Pardo Bazán's assertion that “La esclavitud femenina está apuntalada también por la moda (1908: 730).

The second crossdressing scene is as interesting for its parallels as for its differences. The doctor informs us that: "todas las mañanas, al dejar las ociosas plumas el esposo, una vocecita dulce y aflautada le daba una orden terminante, aunque sonase a gorjeo: --¡Ponte mis enaguas, querido Nicolás! ¡Ponte aprisa mis enaguas!” (Pardo Bazán, 1996: 116). Unlike Nicolás, Clotilde does not change the tone of her voice upon ordering her husband to wear her petticoat, nor does she feel the need to boast about her actions afterwards, as Nicolás did. Furthermore, whereas Nicolás only asks Clotilde to wear his pants once, Clotilde orders her husband to wear her petticoat every morning. The difference in tone suggests that Clotilde position is now such that she does not need to raise her voice in order to be obeyed. Her enigmatic smile, her silences, and her soft voice all serve as covers for her dominance in the marriage and allow her to maintain the image, at least to the outside world, of the submissive wife. Clotilde's repeatedly asking her husband to wear her clothes actually parallels the ways in which she has been required to play the feminine role in society and in her marriage. Thus, the subjugation, in both cases, comes with the imposition of feminine clothes not masculine ones. It is worth noting that the petticoat (enaguas) that Nicolás is forced to wear is precisely one of the items of female clothing that Pardo Bazán claims impedes women's movement (Por Francia y por Alemania 52-53). Thus, it is fair to say that the petticoat itself symbolizes Nicolás's physical restrictions (due to his illness), that keep him, like many women of the time, confined to the home and dependent on his spouse.

To be sure Nicolás's having to wear female clothing is perceived as more humiliating than Clotilde's having to wear men's clothing not only because of the importance Nicolás personally gives to "wearing the pants" in the marriage, but because, as was mentioned above, he must incur the dishonor of assuming the role of the subordinate sex he 
himself so disdains. In her discussion of cross-dressing in Beauty and Misogyny: Harmful Cultural Practices in the West (2006), Sheila Jeffrey's makes the polemical argument that heterosexual men's practices of crossdressing "are not about being 'women' but about adopting the socially prescribed behaviours of a subordinate group in order to enjoy the sexual satisfaction of masochism" (49). Later she adds that "The fact that lipstick wearing is deliciously 'humiliating' for men makes it clear that lipstick represents, for them, women's inferior status. Lipstick does not elevate the status of women [...] but symbolizes subordination" (61). While some heterosexual men may enjoy the masochistic pleasures of dressing up as a woman, Nicolás's transvestism is imposed by Clotilde, and thus more of a representation of her sadism (desire for revenge) than of his masochism (his desire for submission). Nevertheless, it is true that the masculine/feminine, sadistic/masochistic dichotomies in the story are only inverted, not overcome. It is precisely for this reason that Jeffreys sees crossdressing as a non-feminist practice: "Feminists who want to dismantle gender, because they see it as a product of male dominance, do not 'trans' gender, they simply get over it. [...] Transgender politics are fundamentally conservative, dedicated to retaining the behaviours of the dominant and subordinate classes of male supremacy masculinity and femininity" (2006: 48-49). Thus, concerns like those of Herrero Figueroa that crossdressing does not rectify the underlying gender inequality (2010-2011: 67) have some basis since the sadomasochistic masculine/feminine binary remains intact and is only inverted, not subverted. However, Pardo Bazán's intention here appears to be to emphasize the way in which fashion upholds gender hierarchy, which the story does succeed in doing. Moreover, one must ask what true alternatives would a woman like Clotilde have for gender equality in her marriage while her husband was alive. As Cristina Patiño Eirin reminds us, the penal code at the time only called for 15 days in prison for any man who abused his wife (2018: 24). Unsurprisingly, it is not until Nicolás's death, which is ironically portrayed as a misfortune for Clotilde in the newspaper obituary, that she is finally liberated (Pardo Bazán, 1996: 113). As a young widow with economic means she now holds the most enviable position a woman can hold in society as she is entirely independent (no father and no husband) and controls his own purse strings.

Clotilde is a much more enigmatic character than Nicolás because we have no access to her thoughts and feelings. A young women from a family with no economic means, her parents gladly give her off in marriage to Nicolás Abréu: "Clotildita, [...] era mona, bien educada y sin posición ninguna, y los padres se la dieron gustoso, porque Abréu, provisto de buenas aldabas siempre tuvo colocaciones excelentes" (114). The absence of any mention of Clotilde's feelings about the marriage combined with her parents' eagerness to marry her off, and the use of the diminutive "Clotildita" portray her as a mere object of exchange in the transaction between her parents and soon-to-be husband. Herrero Figueroa claims that Clotilde initially represents the ángel del hogar and is consequently an anti-heroine, or, the type of character Pardo Bazán disdained (2010-2011: 64; 65). Indeed, Herrero Figueroa's judgment of Clotilde, and of readers who might approve of her actions, is not favorable (2010-2011: 67): 
Clotilde es antagónica porque encarna la domesticidad femenina, el ideal erróneo que [Pardo Bazán] rechazab[a]. Nada hay [...] de valor, de energía, de esprírtu de superación, de valentía, pese aquella ocurrencia final que nada tiene que ver con la requerida igualdad genérica. Clotilde no deja de ser una revanchista 'enfermerita', por mucho que pueda suscitar la sonrisa cómplice de aquellas lectoras algunas de las cuales llegarían a considerar su reacción como supuesta reivindicación 'feminista.'"

While Clotilde may outwardly portray the behaviors of the ángel del hogar, after the wedding, there is a clear indication that she never internalized this ideal. While we do not know exactly what Clotilde thought about Nicolás's machista display the night after their wedding, the narrator suggests that she viewed it as a betrayal of her ideals of a marriage based on love rather than servitude: “¿Qué pensó Clotilde de la advertencia? A nadie lo dijo; guardó ese silencio absoluto, impenetrable, en que se envuelven tantas derrotas del ideal, del humilde ideal feminino, honrado, juvenil, que pide amor y no servidumbre..." (Pardo Bazán, 1996: 115). In other words, Clotilde never aspired to be the submissive ángel de hogar, but rather hoped for a marriage of affection and equal standing. And although we are told she fulfilled her duties as submissive wife even after Abréu fell ill, it is clear that she enjoys caring for him precisely because she is now in control. We are initially presented with the description of: "la mujer, bonitilla, con cara de resignación alegre, cuidándole solícita, siempre atenta a esos caprichos de los enfermos" (Pardo Bazán, 1996: 111), only to be informed shortly thereafter of her "sonrisilla silenciosa y enigmática" (Pardo Bazán, 1996: 112). Then, we are made privy to the fact that a mere glance by Clotilde was enough to silence her husband during one of his rants: "Generalmente su presencia, una ojeada suya, cortaban en firme las diatribas y catilinarias del marido. No era necesario que murmurase: -No te sofoques, Nicolás; ya sabes que lo ha dicho el médico..." (Pardo Bazán, 1996: 112). There is an inherent contradiction in the doctor's statement that Clotilde both took care of Nicolás with "verdadera abnegación" and that every day she gave him the "orden terminante" to put on her petticoat (Pardo Bazán, 1996: 116).

Considering Clotilde's ability to acquire the upperhand in the marriage the "feminista" of the title of the story appears to be a reference to Clotilde. But, as Joyce Tolliver ponders "Is the author poking fun at the emasculating image of feminists, or is she upholding it?" (Pardo Bazán, 1996: 110). I would argue that the answer depends on the reader and his or her reading of the story. While Clotilde's humiliation of her husband certainly will confirm some people's negative views of feminists, Pardo Bazán's views on fashion and gender, her own relationship to feminism, and her condemnation of gender violence would suggest a different authorial intent. In addition to her critique of the role fashion played in women's subjugation, Pardo Bazán was also unabashed in identifying as a feminist: "Yo soy una radical feminista. Creo que todos los derechos que tiene el hombre debe tenerlos la mujer" (Bravo-Villasante, 1973: 292; qtd. in Tolliver, 1996: 110). Equally relevant is her strong denouncement of violence against women and the way in which "el hombre, en general, cree vagamente que por ser hombre tiene derecho de vida y muerte sobre la mujer" (qtd in Patiño Eirin, 2018: 22). Pardo Bazán spoke out publicly about the law's inadequacy in protecting women from such crimes, about society's general indifference to these crimes, 
and more controversially, about some women's complicity in this behavior (Patiño Eirin, 2018: 22; 25-26; 45, Smith, "La violencia", 2009: 583-585) ${ }^{7}$. Regarding the question of crimes of passion, Pardo Bazán argues that what people call passion is merely men's wounded egos which they prefer to protect at the expense of killing their partners; better to be brought to trial and likely face a lenient and sympathetic judge, than to being publicly shamed in any way by the inferior sex (Smith, "La violencia", 2009, 583). However, Pardo Bazán also criticized women who did not exhibit self-respect by acknowledging men's violence for what it was: egoism, not true affection for the woman (Smith, "La violencia", 2009, 584-585). In light of Pardo Bazán's views on domestic violence, I believe it is safe to assume her sympathies lie with Clotilde. For women like Pardo Bazán, who were tired of seeing women victimized, a tale of revenge on the part of a woman with no status in society, and exercised through the seemingly frivolous, yet highly symbolic and relevant question of fashion, was surely satisfying. It allowed the author to simultaneously denounce domestic abuse and the role women's fashion played in women's subjugation, while exacting a playful form of revenge by making Nicolás wear women's undergarments. As a fictional tale, not a conduct manual, it is safe to assert that one can enjoy the poetic justice without assuming Clotilde's actions are intended as a model to be followed.

Pardo Bazán's identification with Clotilde is reinforced by the similarities between this story and the water color image of Pardo Bazán herself represented slipping on a pair of trousers ${ }^{8}$.

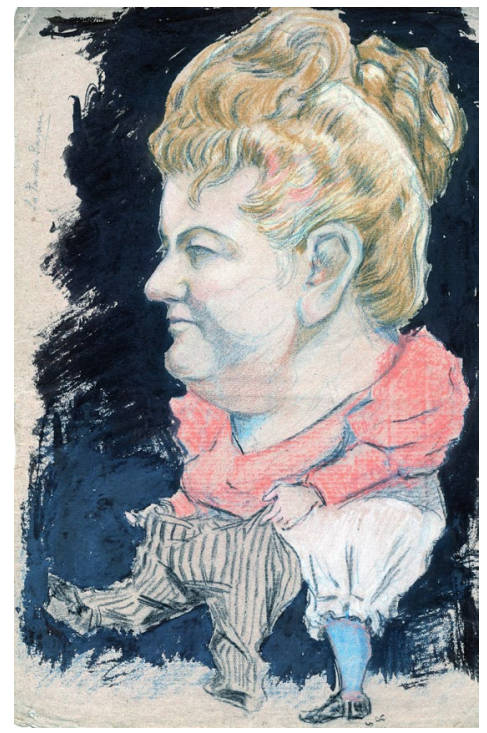

Watercolor of Pardo Bazán (courtesy of Muséu del Pueblu d'Asturies, Gijón)

\footnotetext{
7 Two other useful studies on Pardo Bazán's views and representations of gender violence are R. Ruiz-Ocaña's "Emilia Pardo Bazán y los asesinatos de mujeres" (2004) and Margot Versteeg's "Gender-based Violence in the Short Fiction of Emilia Pardo Bazán” (2010).

8 The origins of this painting are unknown.
} 
What is most notable is that she is not wearing Turkish leglettes or a divided skirt, but clearly a pair of men's trousers, like the ones Clotilde is forced to wear on one occasion, and forbidden from wearing ever again. She also is not wearing a corset or petticoat like the one both Clotilde and Nicolás are forced to wear, but divided knickers, possibly a chemilette like the one she endorsed in "La reforma integral del traje en los Estados Unidos." And of course the bluestocking, a symbol of her status as a literata, carries with it equally charged positive and negative connotations. While the image portrays her with an overly large head and small body as is typical of all caricatures, this portrayal is actually more sympathetic than most of the others done of the author ${ }^{9}$, suggesting that the painter may have admired her and her work, at least to some degree. Still, like the story "Feminista," the interpretation of this image is largely dependent on our own views on feminism and women "wearing the pants." This image dialogs with the story, intentionally or not, and connects Pardo Bazán, bluestocking, advocate of fashion reform for women, critic of domestic abuse, and "feminista radical" with Clotilde, the one-time pant wearing "feminista" of the title of the story who did not let her husband's abuse, sartorial and otherwise, go unchecked, and took symbolic justice into her own hands.

\section{BIBLIOGRAPHY}

Bartky, Sandra (1988): "Foucault, Femininity, and Modernization of Patriarchal Power", I. Diamond and L Quinby (eds.), Feminism and Foucault: Reflections on Resistance, Boston, Northeastern University Press, pp. 61-86.

Bieder, Maryellen (2005): "Picturing the Author: The Private Woman Meets the Public Gaze", Revista de Estudios Hispánicos, núm. 39, pp. 301-329.

Bieder, Maryellen (1993): "Plot Gender/Replotting the Reader: Strategies of Subversion in the Stories of Emilia Pardo Bazán", Indiana Journal of Hispanic Literatures, núm. 2, pp. 137-56.

Bravo-Villasante, Carmen (1973): Vida y obra de Emilia Pardo Bazán, Madrid, Magisterio Español.

Burgos, Carmen (1927): La mujer moderna y sus derechos, Valencia, Sempere.

Butler, Judith (2007): Gender Trouble: Feminism and the Subversion of Identity, New York, Routledge.

Cibreiro, Estrella (2017): Palabra de mujer: hacia la reivindicación y contextualización del discurso feminista español, Madrid, Editorial Fundamentos.

Entwistle, Joanne (2000): "Fashion and the Fleshy Body: Dress as Embodied Practice", Fashion Theory, núm. 4, pp. 323-348.

\footnotetext{
9 For an analysis of pictorial representations of Emilia Pardo Bazán in the Spanish periodical press, see Maryellen Bieder's "Picturing the Author: The Private Woman Meets the Public Gaze."
} 
Etxebarria, Lucía (2000): La Eva futura: como seremos las mujeres del siglo XXI y en qué mundo nos tocará vivir, Barcelona, Ediciones Destino.

Faludi, Susan (1991), Backlash: The Undeclared War against Women, New York, Crown.

Frith, John (2012): "Syphilis - Its Early History and Treatment until Penicillin and the Debate on Its Origins", Journal of Military and Veterans' Health, núm. 20, pp. 49-58.

Henegan, Dorota (2015): Striking Their Modern Pose: Fashion, Gender, and Modernity in Galdós, Pardo Bazán, and Picón, West Lafayette: Purdue University Press.

"Gonorrhea - CDC Fact Sheet (Detailed Version)", Center for Disease Control and Prevention. [Online]. [17 jul. 2019]. https://www.cdc.gov/std/gonorrhea/stdfactgonorrhea-detailed.htm.

Herrero Figueroa, Araceli (2010-2011): “Emilia Pardo Bazán. 'Feminista': desigualdad intergenérica y maltrato doméstico", La Tribuna, núm. 8, pp. 57-70.

"The History of Gonorrhea" (2017), STDAware. [Online]. [17 jul. 2019]. https:// www.stdaware.com/blog/the-history-of-gonorrhea/.

Jeffreys, Sheila (2006): Beauty and Misogyny: Harmful Cultural Practices in the West, London, Routledge, 2006.

Johnson, Roberta (2018): "Fashion as Feminism: Carmen de Burgos's Ideas on Fashion in Context," J. Smith (ed.), Modern Spanish Women as Agents of Change: Essays in Honor of Maryellen Bieder, Lewisburg, Bucknell University Press, pp. 56-70.

López Quintáns, Javier (2013): “Tres textos dispersos de Emilia Pardo Bazán: «La reforma integral del traje en los Estados Unidos (de interés para las damas)», "Más indumentaria, de interés para los dos sexos»y "La mujer periodista»", Revista de estudios filológicos, núm. 26, n. pág. [Online]. https://digitum.um.es/digitum/ bitstream/10201/38115/3/968-3087-1-PB\%20(2).pdf

Pardo Bazán, Emilia [1891]: Cuarenta días en la exposición. Obras completas, núm. 21, Madrid, Administración.

Pardo Bazán, Emilia (2018): El encaje roto: antología de cuentos de violencia contra Mujeres, C. Patiño Eirin (ed.), Zaragoza, Editorial Contraseña, 2018.

Pardo Bazán, Emilia (1996): "Feminista", "El encaje roto" y otros cuentos, J. Tolliver (ed.), New York, MLA, pp. 110-117.

Pardo Bazán, Emilia (1899): Por Francia y por Alemania: Crónicas de la Exposición, Madrid, La España Editorial, [1899].

Pardo Bazán, Emilia (1908): "La vida contemporánea", La ilustración artística, núm. 27, p. 730.

Patiño Eirin, Cristina. "Prólogo en el borde", C. Patiño Eirin (ed.): El encaje roto: antología de cuentos de violencia contra mujeres, Zaragoza, Editorial Contraseña, pp. 9-52. 
Riegel, Robert E. (1963): "Women's Clothes and Women's Rights", American Quarterly, núm. 15, 1963, pp. 390-401.

Ruiz-Ocaña, Ricardo (2004): "Emilia Pardo Bazán y los asesinatos de mujeres", Didáctica (lengua y literatura), núm. 16, pp. 177-188.

Sirin, Selcuk R., Donald R. McCreary, and James R. Mahalik (2004): "Differential Reactions to Men and Women's Gender Role Transgressions: Perceptions of Social Status, Sexual Orientation, and Value Dissimilarity", The Journal of Men's Studies, núm. 12, pp. 119-232.

Smith, Jennifer (2016): “Cultural Capital and Social Class in Emilia Pardo Bazán's 'La mujer española' and Insolación", Anales de la literatura española contemporánea, núm. 41, pp. 143-168.

Smith, Jennifer (2009): "La violencia de género en dos cuentos de Emilia Pardo Bazán", La literatura de Emilia Pardo Bazán, J. M. González Herrán (ed.), A Coruña, Real Academia Galega, Casa-Museo Emilia Pardo Bazán, Fundación Caixa Galicia, pp. 583-591.

Tyner, Keila E. and Jennifer Paff Ogle (2009): "Feminist Theory of the Dressed Female Body: A Comparative Analysis and Applications for the Textiles and Clothing Scholarship", Clothing \& Textiles Research Journal núm. 27, pp. 98-121.

Versteeg, Margot (2010): "Gender-based Violence in the Short Fiction of Emilia Pardo Bazán", Au Naturel. Re-reading Hispanic Naturalisms, J.P. Spicer-Escalante and L. B. Anderson (eds.), Newcastle upon Tyne: Cambridge Scholars Publishing, pp. 135-152.

Walter, Susan (2010): From the Outside Looking in: Narrative Frames and Narrative Spaces in the Short Stories of Emilia Pardo Bazán, Newark, Juan de la Cuesta.

"What Are the Types and Stages of Syphilis?", WebMD. [Online]. [17 jul. 2019] https:// www.webmd.com/sexual-conditions/types-stages-syphilis.

Wolf, Naomi (1992): The Beauty Myth: How Images of Beauty are Used against Women, New York, Anchor Books. 